\title{
UKRAINIAN RADIO METEOR NETWORK — DEVELOPMENT AND FIRST RESULTS
}

\author{
Kulichenko M.O. ${ }^{1}$, Kaliuzhnyi M.P. ${ }^{1}$, Bushuev F.I. ${ }^{1}$, Shulga O.V. ${ }^{1}$, Malynovskyi Ye.V. ${ }^{2}$, \\ Savchuk S.G. ${ }^{3}$, Yankiv-Vitkovska L.M. ${ }^{3}$, Hrudynin B.O. ${ }^{4}$ \\ ${ }^{1}$ Research Institute "Mykolaiv Astronomical Observatory" \\ ${ }^{2}$ Rivne Minor Academy of Sciences \\ ${ }^{3}$ Lviv Polytechnic National University \\ ${ }^{4}$ Oleksandr Dovzhenko Hlukhiv National Pedagogical University \\ niiko4kulichenko@gmail.com,nikalyuzhny@ukr.net,shulga-av@ukr.net
}

\begin{abstract}
The network of the meteor observation in the radio range consisting of 6 stations located in Mykolaiv (3 stations), Rivne, Lviv and Hlukhiv has been created. The main goal of the network is to expand information about meteor phenomena, including the assessment of the kinematic parameters (velocities, radiants and orbital elements) of meteoroids and their relationship with other small bodies of the Solar system (potentially hazardous asteroids approaching the Earth). The operation of the meteor observing hardware and software complex is based on the continuous receving of signals from FM radio station reflected from ionized meteor trains that occur in the Earth's atmosphere at altitudes of $80-100 \mathrm{~km}$. SDR technology is used to receive radio signals from over-the-horizon FM broadcast stations reflected by a meteor train, which has allowed to improve the sensitivity and frequency selectivity of radio signals. In 2017-2020 the network registered 1093015 meteors. The observational data are posted on the RMOB website. Diurnal variation of meteor counts and comparison with Perseids meteor stream activity are presented in the work.
\end{abstract}

Keywords: Meteors, forward scattering, software defined radio $(\mathrm{SDR})$.

АНОТАЦІЯ. Створено мережу спостереження метеорів у радіо діапазоні, яка складається 36 станцій, що знаходяться в Миколаєві (3 ствнції), Рівному, Львові та Глухові. Основною метою мережі $\epsilon$ розширення інформації про метеорні явища, включаючи оцінку кінематичних параметрів (швидкостей, радіантів та елементів орбіт) метеороїдів та виявлення взаємозв'язку 3 іншими малими тілами Сонячної системи (зокрема потенційно небезпечними астероїдами, що зближуються із Землею). Функціонування метеорного апаратурно-програмного комплексу базується на безперервному, цілодобовому прийомі сигналів радіомовної FM станції, відбитих від іонізованих метеороїдних слідів, що виникають в атмосфері Землі на висотах 80-100 км. Використання SDR технології для прийому радіосигналів загоризонтних FM-станцій, відбитих метеороїдним слідом, дало змогу поліпшити чутливості і частотну вибірковість прийому радіосигналів. За час роботи в 2017-2020 pр. мережею було зареєстровано 1093015 метеорних явищ. Спостережні дані у вигляді текстових таблиць погодинних чисел щомісяця відправляються на сайт RMOB. Для підтвердження достовірності даних спостережень проведено: a) перевірку добових варіацій кількості метеорів, зареєстрованих станціями мережі, на відповідність відомій залежності (спостереження метеорів в апексі та антиапексі); б) порівняння отриманих мережею характеристик для метеорного потоку «Персеїди», що спостерігався в серпні 2020 р., на відповідність очікуваним, як у часі появи, так і в інтенсивності. Для підвищення достовірності реєстрації метеорних явищ пропонується провести додаткові дослідження характеристик радіоперешкод, що діють в місцях дислокації станцій, з метою розробки методів їхнього придушення.

Ключові слова: Метеори, пряме розсіювання, SDR технологія.

\section{Introduction}

Forward scattering of radio waves off meteor trails is the most common and accessible way of meteors observation in radio band. The advantage of this way is that transmitter which has enough power is located behind the horizon and the observer only manage receiving station which is relatively easy to build. According to RMOB (Radio Meteor Observing Bulletin, https://www.rmob.org/) 46 observers of radio meteors from all over the world send their data online. Most of them (Europe) receive the signal from french military radar GRAVES, observers from USA receive the signal from VHF radio beacons, observers from Belgium set their own radar station which has small power but stable signal with known parameters. Radio meteor observers also establish networks in some countries: BRAMS (Belgium) (Calders et al., 2018), Bolidozor (Czech Republic) (Kakona et al., 2016). The main information received by radio meteor observers is the number of detected phenomena per hour, which allows both to estimate the parameters of meteor showers (period and peak of activity, observability function) and to monitor the distribution of meteoroid matter during the diurnal and annual cycles of the Earth motion. 
Table 1: Locations of the network receiver stations and their characteristics

\begin{tabular}{|c|c|c|c|c|c|c|}
\hline Location & Latitude & Longitude & $\begin{array}{l}\text { Antenna } \\
\text { height, } \mathrm{m}\end{array}$ & $\begin{array}{l}\text { Frequency, } \\
\text { MHz }\end{array}$ & $\begin{array}{l}\text { Distance between } \\
\text { transmitter and } \\
\text { receiver, } \mathrm{km}\end{array}$ & $\begin{array}{l}\text { Azimuth of antenna } \\
\text { direction, deg }\end{array}$ \\
\hline $\begin{array}{l}\text { Mykolaiv } \\
\text { (Ukraine) }\end{array}$ & $46^{\circ} 58^{\prime} 17^{\prime \prime} \mathrm{N}$ & $31^{\circ} 58^{\prime} 22^{\prime \prime} \mathrm{E}$ & 65 & 88.2 & $\begin{array}{c}905 \text { (Kielce) } \\
715 \text { (Istanbul) }\end{array}$ & $\begin{array}{c}302 \text { (Kielce) } \\
199 \text { (Istanbul) }\end{array}$ \\
\hline $\begin{array}{l}\text { Rivne } \\
\text { (Ukraine) }\end{array}$ & $50^{\circ} 37^{\prime} 23^{\prime \prime} \mathrm{N}$ & $26^{\circ} 14^{\prime} 55^{\prime \prime} \mathrm{E}$ & 205 & 94.8 & 637 (Budapest) & 240 \\
\hline $\begin{array}{l}\text { Lviv } \\
\text { (Ukraine) }\end{array}$ & $49^{\circ} 50^{\prime} 11^{\prime \prime} \mathrm{N}$ & $24^{\circ} 00^{\prime} 52^{\prime \prime} \mathrm{E}$ & 316 & 91.7 & 900 (Sonnenberg) & 278 \\
\hline $\begin{array}{l}\text { Hlukhiv } \\
\text { (Ukraine) }\end{array}$ & $33^{\circ} 54^{\prime} 56^{\prime \prime} \mathrm{N}$ & $51^{\circ} 40^{\prime} 43^{\prime \prime} \mathrm{E}$ & 175 & 88.2 & 900 (Kielce) & 269 \\
\hline
\end{tabular}

Table 2: Locations of transmitters and their characteristics

\begin{tabular}{|l|c|c|c|c|c|}
\hline \multicolumn{1}{|c|}{ Location } & Latitude & Longitude & Antenna height, $\mathrm{m}$ & Power, kW & Frequency, MHz \\
\hline Kielce (Poland) & $50^{\circ} 51^{\prime} 36.29^{\prime \prime} \mathrm{N}$ & $21^{\circ} 02^{\prime} 54.76^{\prime \prime} \mathrm{E}$ & 697 & 120 & 88.2 \\
\hline $\begin{array}{l}\text { Budapest } \\
\text { (Hungary) }\end{array}$ & $47^{\circ} 29^{\prime} 30.17^{\prime \prime} \mathrm{N}$ & $18^{\circ} 58^{\prime} 44.00^{\prime \prime} \mathrm{E}$ & 592 & 100 & 94.8 \\
\hline $\begin{array}{l}\text { Sonnenberg } \\
\text { (Germany) }\end{array}$ & $50^{\circ} 26^{\prime} 48.29^{\prime \prime} \mathrm{N}$ & $1^{\circ} 00^{\prime} 15.78^{\prime \prime} \mathrm{E}$ & 1005 & 100 & 91.7 \\
\hline $\begin{array}{l}\text { Istanbul } \\
\text { (Turkey) }\end{array}$ & $41^{\circ} 00^{\prime} 58.75^{\prime \prime} \mathrm{N}$ & $29^{\circ} 03^{\prime} 56.11^{\prime \prime} \mathrm{E}$ & 384 & 100 & 88.2 \\
\hline
\end{tabular}

Our main goal of creating and developing a meteor observations network using the forward scattering of FM radio broadcasting signals is to expand information about meteor phenomena, including the assessment of the kinematic parameters (velocities, radiants, and orbital elements) of meteoroids and their relationship with other small bodies of the Solar system (potentially hazardous asteroids approaching the Earth).

\section{Hardware and software}

It is possible to observe meteors by forward scattering from FM radio stations which work in frequency band 88$108 \mathrm{MHz}$. Such experiments were started in Ukraine at Research Institute «Mykolaiv astronomical observatory» (RI «MAO») in 2010 (Vovk et al., 2012). During the tenyear research period, hardware and software were developed to observe, extract and calculate the parameters of meteor phenomena (Vovk et al., 2017). Successful work on observations of meteor phenomena and automatic processing of results allowed expanding the number of stations and creating a network of radio observations of meteors in Ukraine. Herewith three network stations were set in RI "MAO", as well as standard station equipment was set in Rivne (Rivne Minor Academy of Sciences for Student Youth), Lviv (Lviv Polytechnic National University), and Hlukhiv (Olexandr Dovzhenko Hlukhiv National Pedagogical University). The RI "MAO" stations were named as "MAIN", "AMC" and "WAGON". The location of receiver stati- ons and corresponding transmitters are given in tables 1 and 2 as well as transmitters power and frequency an distances between receiving and broadcasting stations.

Network station hardware consists of:

1) 6 or 8-elements Yagi-Uda antenna;

2) SDR DVB-T receiver RTL2832U;

3) PC with following minimum requirements: the 150 GB hard drive, $2.0 \mathrm{GHz}$ dual-core processor, 2GB RAM, and 32-bit operating system (OS).

The input information for searching for signals reflected from meteor trains is the signal from the output of the receiver quadrature detector or signal that has not been demodulated yet and whose characteristics fully correspond to the signal in the carrier frequency. Due to the use of such a signal, it is possible to determine the amplitude and Doppler shift of the frequency of the signal reflected from the plasma trail as a result of carrier frequency recovery on a known modulation signal, which is impossible for a signal that has been demodulated and analyzed in Bushuev et al., 2010.

The HDSDR software, which is freely available, is used to record radio signals. The program allows to save recordings of the amplitudes values from the receiver quadrature channels as wav-files and image files of the amplitude-frequency-time plot (waterfall) for continuous monitoring of meteor activity. The minimum bandwidth is $250 \mathrm{kHz}$, and the maximum is $3.2 \mathrm{MHz}$. This is much larger than the spectrum width of the FM signal, which does not exceed $75 \mathrm{kHz}$, and which is necessary for optimal processing of this signal. 


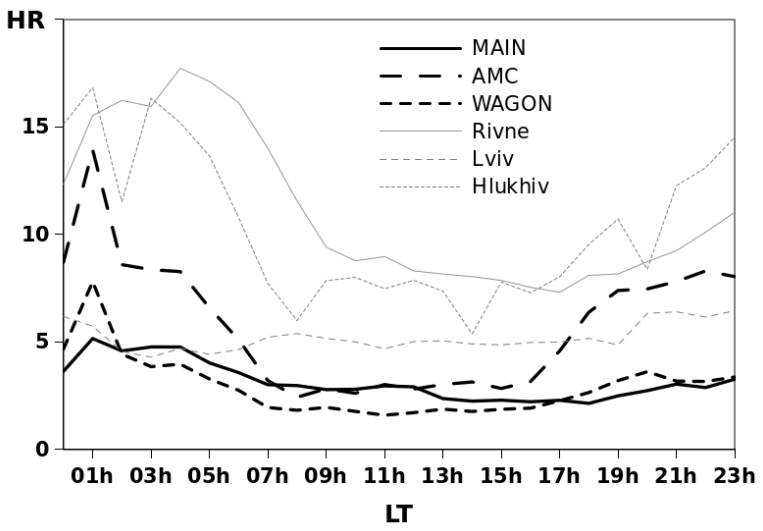

Figure 1: Diurnal variations of meteors HR for each receiving station

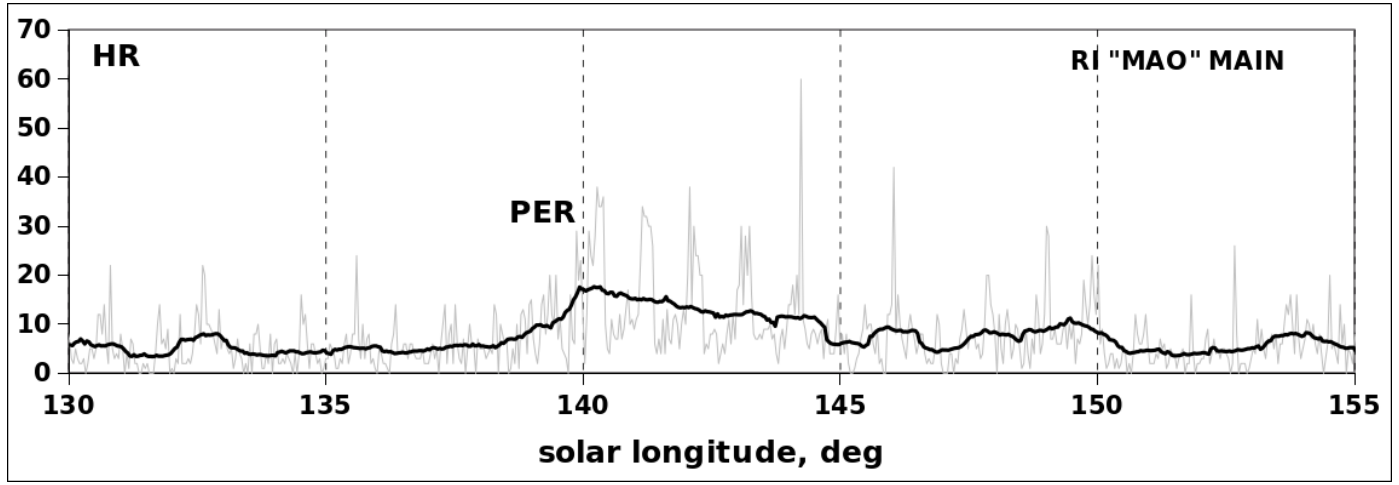

Figure 2: August hourly rate data obtained by RI "MAO" channel MAIN.

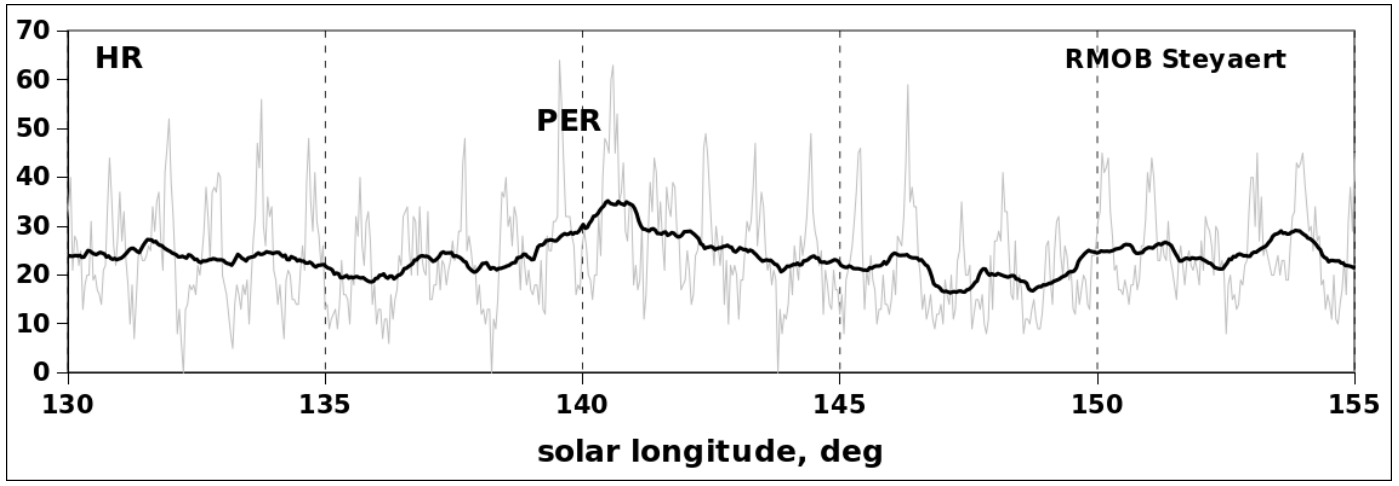

Figure 3: August hourly rate data obtained by RMOB user Chris Steyaert.

Each station provides continuous automatic processing of observational data and automatic e-mailing to users which interested in receiving daily data on space intrusions into the Earth's atmosphere. The method of processing and extracting of meteor phenomena parameters is described in Vovk et al., 2017. Monthly reports are also posted on the RMOB website. The daily amount of processed information per station is about 80 GB.

\section{Results}

Total amount of events identified as meteors registered by the network in 2017-2020 is 1093015. To confirm reliability of meteor phenomena identification the diurnal variation of hourly rate was analyzed. From the early radio meteor research campaigns the certain shape of meteor number variation curve during day and night is found: the maximum of hourly rate (HR) is nearly at $6 \mathrm{LT}$ (local time) and corresponds with meteoroids moving from apex source. The minimum of HR variation is at 17 LT cased by meteoroids of antapex source. Diurnal variations of meteors HR averaged for data observed in 2019 for each receiving station of the network are shown on fig. 1.

From the curves shown on fig. 1, it is seen that for stations in Lviv and Mykolaiv (MAIN) that variations of change in time of meteors quantity do not correspond to 
expected. These features may be caused by the appearance of significant radio interference near the stations in certain periods during the year. Additional research is needed to solve this problem.

Certain character of diurnal variation of meteors HR typically observed when sporadic meteors only registered. For meteor showers another behavior is typical. On fig. 2 and 3 the comparison of August HR data obtained by RI "MAO" channel MAIN (fig. 2) and RMOB user Chris Steyaert (fig. 3 ) is shown. Both curves has maximum near solar longitude $140.0^{\circ}$ which is corresponding with Perseids meteor shower peak activity. HR values on fig. 2 and 3 (gray line) are smoothed by 24 points moving average trend (black line).

\section{Conclusion}

The network of observations of the meteor phenomena in a radio range consisting of 6 stations located in Mykolaiv (3 stations), Rivne, Lviv and Hlukhiv is created. In 2017-2020 the network registered 1093015 meteor phenomena. The registration results are posted on the RMOB website. To confirm the reliability of these observations, the following was performed: a) verification of daily variations in the number of meteors registered by network stations for compliance with the known dependence (meteor observations in the apex and antapex); b) comparison of the characteristics obtained by the network of major meteor showers (Perseids were chosen as an example) for compliance with the expected both at the time of peak activity and intensity. To increase the reliability of registration of meteor phenomena, it is proposed to conduct additional studies of the characteristics of radio interference operating in the locations of stations in order to develop methods for their suppression.

\section{References:}

Bushuev F.I. et al.: 2010, Cosm. Sci. and Tech., 16 (6), 68. Calders S. et al.: 2018, The Radio Meteor Zoo: involving citizen scientists in radio meteor research. European Planetary Science Congress EPSC2018-148.

Kakona J. et al.: 2016, preprint (arXiv:1606.02052).

Vovk V.S. et al.: 2012, Astroschool Report, 8 (2), 166

Vovk V.S. et al.: 2017, Sci. and Inov., 13 (1), 70. 